\title{
A green economy?
}

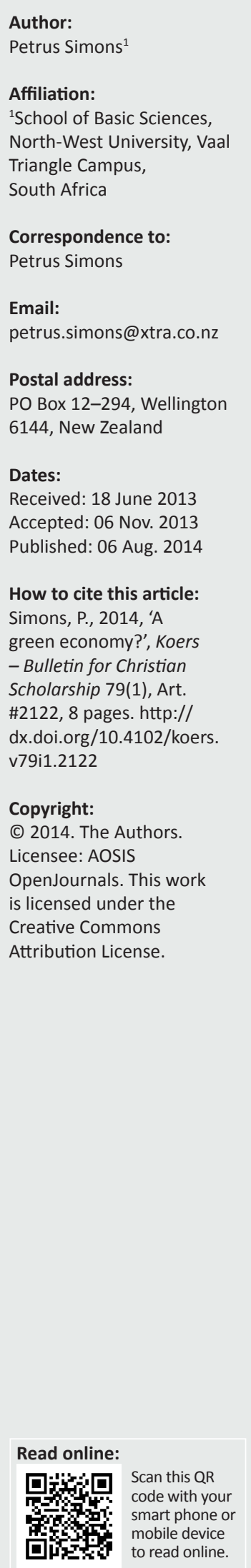

Economic growth has become a fetish, as it is believed to yield many benefits to society. It has its origins in the Enlightenment ideal of progress through science, technology and a free market economy. J.W. Goethe anticipated the problems of such progress in his poem Faust, especially its second part. Binswanger interprets Goethe's view on the modern economy as a form of alchemy, an attempt to master time through the invention of monetary capital. Keynes's views on progress and liquidity are compatible with this analysis. The problems, evoked by the uncritical application of scientific technology so as to increase material welfare, have given rise to a dialectic between business seeking growth and those concerned about its effects, especially on ecology. Sustainable development is an outcome of this dialectic, without abandoning it. Others, particularly those advocating décroissance [de-growth], reject the concepts underlying growth. The ideology underlying this is a combination of technicism and economism. A spiritual revolution is called for to break the hold of this ideology on society, with a change from the metaphor of the world as a machine to that of a garden-city. It is suggested that working groups should analyse the various proposals for change from the perspective of the garden-city metaphor.

'n Groen ekonomie? Ekonomiese groei het in 'n fetish ontaard en daar word geglo dat dit vele voordele vir die samelewing inhou. Die oorsprong hiervan kan in die Verligtingsideaal van vooruitgang deur wetenskap, tegnologie en 'n vryemark ekonomie gevind word. J.W. Goethe het die probleme van vooruitgang in sy gedig Faust, veral die tweede gedeelte daarvan, geantisipeer. Binswanger interpreteer Goethe se siening van die moderne ekonomie as ' $n$ vorm van alchemie en as 'n poging om tyd deur die uitvinding van monetêre kapitaal te bemeester. Keynes se sienings van vooruitgang en likiditeit is versoenbaar met hierdie analise. Die probleme wat deur die onkritiese toepassing van wetenskaplike tegnologie ter wille van die toename in materiële welvaart opgeroep is, het aanleiding gegee tot ' $n$ dialektiek tussen besigheid opsoek na groei en diegene wat bekommerd is oor die gevolge daarvan, veral die ekologiese gevolge. Volhoubare ontwikkeling is 'n uitkoms van hierdie dialektiek, sonder dat dit agtergelaat word. Ander, veral diegene wat décroissance [de-groei] voorstaan, verwerp die konsepte wat groei onderlê. Onderliggend hieraan is ' $n$ ideologie wat 'n kombinasie van tegnisisme en ekonomisme is. 'n Spirituele revolusie is nodig om die houvas wat hierdie ideologie op die samelewing het, te verbreek. Dit sluit in dat die huidige metafoor van die wêreld as 'n masjien na ' $n$ metafoor van 'n tuin-stad moet verander. Daar word voorgestel dat werksgroepe die verskeidenheid voorstelle vir verandering vanuit die perspektief van die tuin-stad metafoor analiseer.

\section{Introduction}

Economic growth (an annual percentage increase in the monetary value of goods and services produced (gross domestic product [GDP]) has become a fetish or idol inasmuch as it is supposed to have powers beyond the mere production of goods and services.

The question is why it has become a fetish and what the consequences are if it carries on unchecked, especially for all that is (and is not yet) expressed in monetary terms.

The German poet, statesman, scholar and alchemist Johann Wolfgang von (since 1782) Goethe (1749-1832) was acquainted not only with the economic literature of his day but also with economic practice as government minister and advisor in Weimar. He anticipated the problems of economic growth, including ecological devastation, especially in part II of Faust (see Goethe [1832] 1994). According to Hans C. Binswanger (2005), Goethe appreciated the modern economy that was emerging in his days as a form of alchemy.

In contrast, John Maynard Keynes, one of the 20th century's most eminent economists, who was also an important public servant in Britain, saw a great future for the grandchildren of his 
generation, marked by technical innovations, provided they continued to rely for 'a little longer still' on 'the gods of avarice and usury and precaution', for 'only they can lead us out of the tunnel of economic necessity into daylight' (Keynes [1930] 1952:372). Ecological problems did not darken his horizon.

This article opens with a definition of growth and why it can be called a fetish. The analyses by Goethe and Keynes are summarised, with reference to Binswanger's view on Faust Part II and Skidelsky's of Keynes's mistake of ignoring the insatiability of wants (see Skidelsky \& Skidelsky 2012).

By using the viewpoint of stocks, stows and flows, and transformations, the disconnection between the technicaleconomic system and the ecology can be shown. This leads to a discussion of technicism and economism. Keynes's 1930 dream of a good life in 100 years stands in contrast to the recent sway of neo-liberalism, a form of economism.

Technicism and economism raise opposition so that a dialectic emerges between business and those concerned about the environment, leading to sustainable development. Décroissance is the most radical opponent of indefinite growth, but lacks a coherent guide towards an alternative cultural development such as is suggested by Schuurman's metaphor of a garden-city.

\section{Economic growth defined}

Economic growth is defined as the increase in GDP per person. This product is measured in money, albeit with inflation removed. The theory of economic growth seeks to understand how an economy may achieve long-term growth. From its beginnings in the 1950s the theory has focussed on factors such as increases in the population, the stock of capital and technical efficiency. The theory has become very involved with a wide range of models and approaches. Nevertheless, Solow (1987:140), one of the key theorists, concluded his review of policies for economic growth by emphasising 'the importance of physical, human and technological investment'.

In practice, politicians seek to stimulate economic growth in order to reduce unemployment, to improve social welfare or to have the means to clean up the environment.

Statistics of GDP growth allow comparisons and, hence, competition, between countries. Skidelsky and Skidelsky (2012) sees this as one of the reasons why:

we maintain a system which continues to celebrate acquisitiveness at the expense of enjoyment. Our leaders can offer no more than a continuation of economic growth for ever and ever; and this despite the plentiful evidence that the capitalist system in our part of the world is entering its degenerative phase. (pp. 180-181)

Yet Skidelsky, father and son, are not condemning all forms of economic growth. They take aim at our obsession with acquiring more and more goods and services. Such obsession is typical of a fetish.

\section{Economic growth as a fetish}

According to H. Böhme (2006) a fetish involves a corrupt relationship to things. The Enlightenment philosophy defined fetishes as things to which one ascribes meanings and powers beyond their primary properties. For fetishists such things not only incorporate these powers but also radiate them. When Charles de Brosses introduced this concept into philosophy in 1760, he saw it as something negative, contrary to the spirit of the Enlightenment (H. Böhme 2006:17).

During the 19th century, there was an enormous increase in things produced and sold. Shopping centres could be called 'cathedrals' of goods because they presented, almost ritually, hundreds of things that fascinated customers, whose dwellings became full of things (H. Böhme 2006:18). This has carried on up to our day. The publicity industry thrives on endowing goods advertised with powers to make us happy or fulfilled.

Karl Marx (1818-1883) appreciated money as a fetish inasmuch as it transforms things into exchangeable goods and incorporates also the relationships between the people who produce and exchange goods H. Böhme (2006:319-323).

In modern production systems one works not so much to make useful goods (use value) but rather to produce things that can be sold for money (exchange value). Money or profit is what matters. Profits made are re-invested into new capital investment. The system keeps expanding. In the 19th century new markets were found in colonies. Human labour and money have become abstractions. Employment, people in general, and nature should adapt to the demands of the production 'machine'. If dams are needed to generate power, people who have lived there for centuries are displaced. Farmers should give up fertile land for coal mines or airports.

This system is compatible with a market economy, a socialist system of state capitalism or a mixed economy in which state enterprises work alongside the market economy and in which the state tries to guide the economy through prices and incomes policies. It relies on the application of science in technology through capital investment as a basis for economic growth.

The German poet, Johann Wolfgang von Goethe (1749-1832), gauged the basics of the great enterprise of conquering nature by means of science, technology and money or capital in his poem Faust (see Goethe [1832] 1994). G. Böhme has pointed out that Faust is a didactic poem, an allegory designed to show how the substantial relationships of feudalism, monarchy and agriculture were being transformed into abstract relationships and with nature becoming a resource for production. In this way, Goethe's analysis is similar to Marx's (G. Böhme 2005:174-175).

\section{Alchemy: Goethe's Faust}

Another view on Faust is presented by Binswanger (2005). His view on Faust, especially part II, is that Goethe saw the modern economic system as a form of alchemy. Alchemy is characterised by five features: 
1. There are four elements: air, water, fire and soil, which contain the quintessence (prime matter) or fifth element, the philosopher's stone. This stone, when distilled from the four elements, serves as a catalyst to achieve a transmutation of perishable into imperishable noble metals such as gold. Gold is already part of all the four elements. Alchemy, therefore, does not acknowledge a difference between living and non-living things.

2. It attempts to triumph over time, the agent of the perishable. Alchemists try to achieve in a few weeks what might take nature centuries.

3. By mixing living and non-living, one returns to primordial chaos to refashion creation.

4. The outer form of prime matter is determined by sulphur (masculine, related to sun, gold and fire) and mercury (feminine, related to the moon, silver and water). In the opus magnum, the process of distilling the philosopher's stone, sulphur, mercury and salt form the three steps towards obtaining the quintessence.

5. Gold is understood as imperishable in a material (health, or eternal youth; wealth or money) as well as in an immaterial spiritual sense (absolute, i.e. not dependent on our subjectivity). Money resembles gold because it does not wear out and may be multiplied at will (Binswanger 2005:14-17).

Goethe (1832] 1994) analysed the modern economy in terms of the three steps of the magnum opus.

Solutio (mercury dissolves metals): Issue of banknotes: Banknotes are issued over the Emperor's signature. They represent the precious metals hidden in the earth. Thus, valueless material such as paper is converted into valuable money. In Goethe's view, this is the alchemist core of the modern economy, because money enables a steady growth of the economy. In contrast, Adam Smith believed that wealth is created by labour. Modern economics has modified Smith's view somewhat by designating capital and technical innovation also as factors of production, albeit with each being a result of human endeavour (saving and education or research respectively).

Coagulation (sulphur solidifies mercury): Private property or dominium: Money should be invested in new productive projects. The key to this is private property understood as somebody having full and sole control over it. It should be acquired by naked power, greed and possessiveness. Instead of human labour, the powers of nature, especially energy, should be harnessed to create value.

Fixativum (salt as symbol of body or solid mass as fixed point): The Emperor grants Faust a strip of land that is subject to flooding. A grand project of land reclamation, a magnum opus, is undertaken to secure it as productive property. Once people start dwelling in it, trade is called for, the third stage in the alchemic process. Mercury or Hermes is also the god of trade, with ships sailing the oceans (mercury and water) to turn penury into gold (sale value in excess of costs). However, since trade is uncertain, it should be complemented and replaced by manufacturing fed by mechanical energy (steam engines) and designed by science and technology. This results in massive capital investment (Binswanger 2005:24-47).

Given that the philosopher's stone must be able to enhance the value of money, its economic equivalent must be capital, because it creates more money when (successfully) invested. In this way, the only thing that humankind is able to create or to add to the given creation is money or capital, through which the future is anticipated and time overcome (Binswanger 2005:71).

Interest and profit play key roles in this, inasmuch as they can only be realised when the sum of all incomes exceeds all expenditures, which happens only when there is a steady influx of money into the economy. If not enough gold is mined, then, new credit must be obtained to finance new projects. The interest payable on these loans must be warranted by the profits of the new ventures. Thus, ever more real capital is created, which appropriates ever greater parts of nature. A swamp has no monetary value, but when it is drained and used for a factory or a mine, it will be valuable (Binswanger 2005:45).

To summarise: gold hidden in the earth is the prime matter. The quintessence of this gold is the value of the paper money (mercury), the monetary value of property (sulphur) and the monetary value of real capital (salt).

In principle there is no limit to the creation of monetary values. Technical-economic progress is believed to be infinite. Yet we live in a finite world. Our 'progress' is such that the energy radiated by the sun to earth is insufficient to prevent an increase in entropy, visible in growing pollution, waste, declining bio-diversity and destruction of the natural environment. Goethe ([1832] 1994) foresaw this in three ways:

1. Disappearing beauty.

2. Increasing risks and uncertainty inherent in technical progress.

3. An inability to enjoy wealth, especially since producers are reliant on future profits by working for markets. Capital is invested to yield future profits and is, therefore, a source of worry.

As major projects are undertaken, they generate unexpected problems or accidents, sometimes after decades. Faust refuses to accept worries about such things. Problems should be tackled with more science and technology. His belief remains unshaken that by reinvesting profits continuously, a stream of future profits comes into being to keep the present value of the capital constant. The future becomes present and the present is timeless (Binswanger 2005:73-78).

\section{Stocks, stows, flows and transformations}

Another way of describing the issues raised is to look at nature as consisting of stocks of materials, such as uranium 
prior to nuclear technology, flows of various kinds such as sunshine, rain, emissions of gas, lava etc. and transformations such as nectar into honey. Once humans discover what can be done with stocks, they deploy tools to turn them into flows of materials that can be technically transformed into flows of products. Flows may accumulate into stows and be turned into flows later in time. Technology is embodied in stows of assets that take in flows for transformation into other flows (Simons 2011).

Flows of money issued may accumulate as savings and be transformed into investments, resulting in flows of wages, rents and profits. An economy can be described as sets of flows, stows and transformations, both financial and real. Its ecological impact consists of flows of pollutants, stows of waste materials and greenhouse gases in the atmosphere. Flows of pesticides may cause the collapse of beehives. Flannery (2013) reviews a book on how over-fishing, climate warming and eutrophication (dead zones caused by fertiliser run-off) have been expanding jelly-fish blooms, which, in turn, help speed up climate warming.

One of the greatest transformations of the modern technicaleconomic system is that of carbon stored in the earth as coal, oil and gas produced slowly through photosynthesis over long periods of time, into energy and flows of carbon-dioxide and other greenhouse gases at a fast pace as much energy is required to power fast running machinery.

When Goethe ([1832] 1994) composed Faust the first Industrial Revolution, based on the power of steam, was in full swing. Towards the end of the 19th century the second revolution began, featuring mass production in factories using assembly lines and electric power (Fordism). We are now in the midst of a third revolution based upon computers and other electronic devices, including the Internet. Each revolution has had major impacts on production, consumption and employment. Each of the technical systems involved relies on energy, most of which is generated by burning fossil fuels. The system has been expanding across nature and across the whole world.

These revolutions have come about because of a belief that every new technology is good and will stimulate progress. One never stops to enquire about any possible downsides. The need to make money under competition or to improve military defence systems is a powerful stimulant of technical innovation.

The financial system has not only collected savings for transformation into capital, it has also become a major speculator in shares, raw materials, food products, houses and companies. Supercomputers, the Internet and sophisticated algorithms have enabled high-speed speculation. As long as financial products, including business companies, can be quickly sold or purchased (that is, as long as they are traded in liquid markets), speculation may be profitable. Keynes ([1936] 1973:155) argued that such speculation was anti-social, because 'the social object of skilled investment should be to defeat the dark forces of time and ignorance which envelop our future'. The latter would be the subject of determining the yields of an investment in the long run. He called the maxim of holding 'liquid' securities 'the fetish of liquidity' (ibid:155).

The reference to 'the dark forces of time and ignorance' implies a belief that present long-term capital investment will yield economic and social benefits, reflected in a present value of future profits at least equal to the cost of the investment.

The ecological flows, stows and transformations are very much at the heart of concerns about the effects of exponential economic growth, which is now engaged in and affects the whole world.

\section{Technicism and economism}

The ideology of progress through capital investment is an expression of technicism, a belief that what can be made should be made. In Schuurman's (2003) words:

Technicism is the pretension of humans, as self-declared lords and masters using the scientific-technical method of control, to bend all of reality to their will in order to solve all problems, old and new, and to guarantee increasing material prosperity and progress. By means of their technology humans want to control and safeguard the future. This technicism answers to two important norms as though they are the two great commandments: the norm of technical perfection or effectiveness and the economic norm of efficiency. (p. 69)

Schuurman's (1995:138) view that technicism seeks to control the future confirms Goethe's ([1832] 1994) analysis. He argues that in our society: 'technological push has priority over economic pull. Science and the economy as such are usually interpreted technicistically, whereupon via positive feedback, they reinforce technicism'.

Nonetheless, there is reason to use the term economism for our obsession with money and 'making money', even if it is subordinate to a belief in the saving power of scientific technology. Money functions as a means of grasping greater material prosperity.

Schuurman's (1995) remark that technicism imposes a commandment to be efficient is apt in the sense that it shows up its true nature. A business corporation which is totally efficient may at the same time be totally wasteful and destructive. To avoid this trap, he notes:

'The economic norm of stewardship must also be honoured, but not to the exclusion of the others'; and when we do this, 'we can prevent a kind of overdevelopment in producing surpluses and restore a kind of underdevelopment in being stewardly in dealing with nature'. (Schuurman 1995:97-98)

\section{Keynes on progress}

In 1930 J.M. Keynes (1883-1946), sang the praises of technological progress as a means towards a good life 
when he considered the outlook for the grandchildren of his generation. Referring to the magnificent technical and scientific discoveries since the 16th century as well as the power of compound interest, he noted:

All this means in the long run that mankind is solving its economic problem. I would predict that the standard of life in progressive countries one hundred years hence will be between four and eight times as high as it is to-day. There would be nothing surprising in this even in the light of our present knowledge. It would not be foolish to contemplate the possibility of a far greater progress still. (Keynes [1930] 1952:364-365)

Keynes ([1930] 1952) associated the economic problem with absolute needs, which we feel 'whatever the situation of our fellow human beings may be' and which we will soon be able to satisfy. However, there are also needs that spring from 'the desire for superiority' and which 'may indeed be insatiable' (ibid:365). He goes so far as to suggest that nature has evolved us to solve the economic problem. Once it is solved, we are deprived of our traditional purpose. This, of course, will be a traumatic experience for many people because they will find it difficult to lose their old habits of money-making. Nevertheless, gradually, a paradisal (my word) situation will emerge. The pace of progress towards this depends on:

1. Controlling population growth.

2. Avoiding wars and civil dissensions.

3. Entrusting to science the direction of those matters which are properly the concern of science.

4. Controlling the rate of accumulation as fixed by the margin between our production and our consumption; of which the last will easily look after itself, given the first three (Keynes [1930] 1952:373).

Finally, Keynes ([1930] 1952:373) cautions against overestimating the importance of the economic problem. It should be a matter for specialists - like dentistry. If he were to revisit his essay today, he would shake his head over our inability to avoid wars and arms races, let alone control the rate of population growth. He might also have been astounded at the strength of the need for superiority as a strong motivator of modern consumerism and 'economic growth'. This idea, articulated first by Thorstein Veblen (1857-1929) in his Theory of the Leisure Class, is driving the world into the abyss of environmental destruction (see Veblen [1899] 2001), because, as Kempf (2007) argues, we admire the standard of life enjoyed by the rich and super-rich, regardless of their conspicuous waste, and try to emulate them, if necessary by going into debt.

Indeed, according to Skidelsky and Skidelsky (2012:41): 'Keynes's mistake was to believe that the love of gain released by capitalism could be sated with abundance, leaving people free to enjoy its fruits in civilized living'. He assumed erroneously 'that material wants are naturally finite' (ibid:69).

Addressing the question why capitalism has had this effect, Skidelsky and Skidelsky (2012) evokes the Faustian bargain struck by capitalism: with the forces of darkness, in return for which it would secure what earlier ages could only dream of - a world beyond the toil and trouble, violence and injustice of life as it actually is. (p. 43)

We are yet to enjoy a favourable outcome of this bargain. Unemployment has become structural due to advancing technology eliminating more jobs than it creates. In an earlier publication, Keynes (1920) appreciated this point when he discussed the economic situation before the Great War (19141918). As Germany had experienced a rapid transformation from an agricultural and self-supporting economy 'into a vast and complicated industrial machine', it had to produce at full tilt to employ the increasing population and to provide it with their subsistence from abroad: 'The German machine was like a top which to maintain its equilibrium must progress ever faster and faster' (ibid:11).

In today's world, with about one billion people struggling to meet their 'absolute needs', many might say that the world still needs a spinning top. As economic policies turned to neo-liberalism in the 1980s, a market economy, run by private enterprise, is believed to provide such a spinning top. It would spin through competition and technical innovation. It is believed to lift people out of poverty through the rich spending their wealth (trickle-down effect) without assistance from the taxpayers. Inequality of income and wealth should therefore be accepted.

\section{Neo-liberalism}

Indeed, neo-liberalism has become a way of life, a norm, for all societies. Dardot and Laval (2009) describes it as follows:

This norm enjoins everybody to live in a universe of generalised competition, summons populations to enter into an economic battle with each other, prescribes that social relationships should be shaped as markets, and transforms even individuals by encouraging them to think of themselves as companies. (p. 5, [author's own translation])

Neo-liberalism strengthens technicism and economism by harping on the ability of markets to solve all problems and singing the praises of small states which balance their books and do not own any businesses. Private enterprise, technical innovation, free international trade and flexible labour markets (meaning that wages should be as low as possible) should be the means to a growing economy.

\section{Dialectics}

Technicism and economism or fetishes arise when parts or aspects of the world are elevated to absolutes. Terms such as -isms, fetishes or idols may be used. Invariably, this generates opposition from those who believe that the worth of the suppressed or oppressed parts or aspects should be defended.

The problems caused by economic growth, especially those involving people and the environment, have given rise to policies that protect the employed, allow trade unions and impose environmental regulations. 
Business corporations adapt to such regulations, but without giving way to the profit motive. Since the 1970s, it has become fashionable to evoke sustainable development or green growth as a guide to business and politics. This movement has been aided by sharp increases in the prices of crude oil and natural gas, making renewable forms of energy profitable.

A problem with sustainable development is that it lacks a precise definition. Moreover, it assumes that the standard of life of the West, once put on a sustainable basis, can be universally applied across the world.

It is for such reasons that sustainable development is rejected by a diverse group of people working under the label of décroissance [counter-growth or de-growth]. As the name suggests, they are mainly French. They all oppose indefinite or exponential GDP growth and want to open some radically new perspectives (Bayon, Flipo \& Schneider 2010:96).

\section{Décroissance or counter-growth}

The movement of décroissance draws on a wide range of sources, including Neo-Marxism, philosopher Ivan Illich, economic-ecologists such as N. Georgescu-Roegen, Howard T. Odum and Kenneth E. Boulding (from cowboy economy to spaceship earth), as well as cultural critics such as Karl Polanyi (who argued that during the 19th century a great transformation took place as money, land and work were monetised).

In 2008 Herman Daly endorsed the idea of décroissance because he believed that the scope of the industrial economy had grown well beyond what eco-technologies might be able to put right (Bayon et al. 2010:41).

Décroissance includes dimensions such as participatory democracy, anti-utilitarianism, as represented by a group of French economists and sociologists such as Serge Latouche and Alain Caillé (groupe MAUSS). They emphasise that at the heart of what is human one finds the notion of gifting: to give, to receive, and to give back. Homo economicus, who turns private vices into public benefits through an invisible hand, but thereby destroys social relationships, should give way to a Homo donator (Bayon et al. 2010:52).

Décroissance rejects the Cartesian idea of nature as a machine. One cannot experiment with an ecological system because irreversible evolutions may occur. In this respect climate warming is a huge experiment with the planet and its inhabitants. Administering small but regular doses of dangerous materials such as pesticides or emissions of greenhouse gases may cause major problems after a period such as the collapse of beehives, male infertility and rising sea-levels.

It is generally assumed that scientific technology should carry on. However, little debate takes place about the implementation of new technologies. Enormous capital expenditures are needed to develop nano- and biotechnologies with unknown effects on human health or the environment. People tend to protest against major infrastructural projects such as dams, nuclear power stations, deep-sea drilling for oil or motorways. In effect, these protests seek to free human life from the impositions of the technical-economic system necessitated by a growing division of labour. Technology should serve progress rather than the ecology (Bayon et al. 2010:103-119, 226).

In terms of new policies, décroissance is still developing ideas. However, Latouche (2004) has proposed a practical way of eight Rs to counter 'over-development, over-fishing, etc.', as follows:

1. Re-evaluate: What do we believe; what are we trying to achieve? What are our values?

2. Restructure: New values should lead to different patterns of production and consumption and new ways of relating to other people.

3. Redistribute: Strive for a much more equal distribution of wealth and income and limit access and use of the world's natural heritage.

4. Reduce: We should reduce the impact of our production and consumption on the environment.

5. Re-use: Rather than buy new products, use the old ones, if possible by revamping them and improving their energy efficiency.

6. Recycle: The wastes resulting from our consumption and production 'should be recycled rather than thrown on rubbish heaps or dumped into the sea' (p. 99).

The trick is to map out a path where one $\mathbf{R}$ facilitates the achievement of other R's. Importantly, Latouche (2004) suggests that Redistribution is important. Without ensuring that social justice improves, there is little point in working towards the other five Rs.

With regard to $\mathbf{R}$ 3, a much higher progressivity in the taxation of wealth and income is of prime importance, as it would curb the inclination of the super-rich to own and use private jets, super yachts, and so forth. A higher taxtake might make it possible to introduce advertisement-free television channels.

Furthermore, the burden of taxation should be shifted from labour to energy.

However, no matter how good these proposals are, they do not deal sufficiently with the spiritual sources of the modern fetishes of growth and scientific technology. Although décroissance has rejected the metaphor of the earth as a machine, it has yet to come up with an alternative metaphor for a cultural development.

\section{A spiritual revolution}

Egbert Schuurman has suggested that our culture needs a spiritual revolution (2003:211), which would involve 
adopting the metaphor of a city-garden (see Gn 2, Is 35, Ezk 47, Rv 21). In a garden, plants and animals are treated as subjects in their own right rather than as objects to serve us. A garden should also display qualities such as harmony, diversity, peace, nurture.

Guided by a city-garden metaphor, we start out on a journey that will bring not only joy but also strong resistance from interests vested in the current technical-economic system. The rule of Christ always involves cross-bearing. The important question is: Are we prepared to walk a new road and bear the crosses it may bring?

Theologian Raymond Pelly (2011) has suggested that Philippians 2:5-11 points to a pattern of self-emptying (What gets in the way of our ability to confront, say, the eco-crisis?), self-limiting (What purchases make our life-styles ecofriendly?) and relinquishment (What do we have to give up to head off a fossil-fuel-driven global warming crisis?).

The relinquishment of many modern things, however, could be compensated for by the pleasure of using solar energy and the enjoyment of more intense friendships, convivial neighbourhoods, and so forth. (see Bernard, Cheynet \& Clémentin 2003:214-216).

In a speech read to students a few years ago, Bob Goudzwaard emphasised the need for a new orientation:

'The deepest crisis of our time is the modern view of the world and the belief that in a secularised world there is in fact no alternative to that modern view, unless in this crisis people begin to see that the real world is still there, a created world with given norms and with proper boundaries within which a good life is still possible'. (Goudzwaard n.d., [author's own translation])

\section{Towards a good life}

In their case for the good life, Robert Skidelsky (economist) and his son Edward (philosopher) are 'challenging the current obsession with the growth of GDP as the chief goal of economic policy'. They 'want leisure to grow and pollution to decline' because they believe that 'the unending pursuit of wealth is madness' (Skidelsky \& Skidelsky 2012:3, 4, 8).

They have identified seven basic goods that should be cultivated and which should have four characteristics, namely:

1. Universal: They should belong to the good life as such and not to a particular conception of it.

2. Final: They are good in themselves, and not just a means to some other good.

3. Sui generic: They are not part of some other good.

4. Indispensable: Everyone who lacks them may be deemed to have suffered a serious loss or harm. They are needs rather than wants.

They have identified seven goods that meet these criteria, that is:
1. Health or the full functioning of the body. They oppose the 'new ideal of perpetual improvement, noting that 'modern science has rekindled the old alchemical promise of eternal youth' (Skidelsky \& Skidelsky 2012:155).

2. Security or an individual's justified expectation that his life will continue more or less in its accustomed course, undisturbed by war, crime, revolution or major social and economic upheavals.

3. Respect, or regarding someone's views and interests as worthy of consideration.

4. Personality, the ability to frame and execute a plan of life.

5. Harmony with nature.

6. Friendship, or all robust affectionate relationships.

7. Leisure, doing what we do for its own sake (Skidelsky \& Skidelsky 2012:150-179).

Of course, it would take a major and on-going programme of work to secure these seven basic goods for everybody in all countries. Health, for instance, requires the provision of nutritious food and good houses. To achieve these one needs to cast a critical look, for instance, at industrial agriculture, supermarkets and fast-food providers.

Uchatius (2009:15-18) is right that nobody knows what a post-growth economy looks like. At this stage, only parts of such an economy are available. He refers in particular to regional currencies that function alongside official currencies. They assist local business and employment. Uchatius quotes Binswanger's proposals to reduce the urge to grow, such as changing business companies financed by shares into foundations. They would have to be profitable, but would not be pressured to achieve $25 \%$ profit. He would also charge central banks with strict controls on bank money.

It would be good if working groups were set up to examine all proposals currently available, including also Riccardo Petrella's (2004) to reintroduce commons to secure the right to life and Monbiot's (2006) to ration the emission of carbon dioxide.

Such working groups might test their proposals against the core ideas of the modalities distinguished by reformational philosophy and emphasised by, amongst others, Schuurman. It means that no one area of life should be supreme.

\section{Conclusion}

The current growth ideology leads to the dead end of a devastated environment and pronounced human suffering. Eventually, growth will become impossible. A new way of economising, with an emphasis on basic goods or needs rather than wants should be sought urgently. Stepping out in a new direction will gradually open new opportunities for a society marked by an abundant life within long-term environmental constraints and social justice guided by the biblical metaphor of a garden-city. 


\section{Acknowledgements}

\section{Competing interests}

The author declares that he has no financial or personal relationship(s) that may have inappropriately influenced him in writing this article.

\section{References}

Bayon, D., Flipo, F. \& Schneider, F., 2010, La décroissance: 10 questions pour comprendre et en débattre, La Découverte, Paris. PMCid:PMC2979715

Bernard, M., Cheynet, V. \& Clémentin, B., 2003, Objectif décroissance: Vers une société harmonieuse, Silence, Lyon.

Binswanger, H.C., 2005, Geld und Magie: Eine ökonomische Deutung von Goethe's Faust, Murmann, Hamburg. PMCid:PMC1449436

Böhme, G., 2005, Goethe's Faust als philosophischer Text, Die Graue Edition, Zug. PMCid:PMC1557770

Böhme, H., 2006, Fetischismus und Kultur, Rowohlt, Hamburg.

Dardot, P. \& Laval, C., 2009, La nouvelle raison du monde: Essai sur la société néoliberale, La Découverte, Paris.

Flannery, T., 2013, 'They're taking over', New York Review of Books, 26 September 2013, pp. 14-18.

Goethe, J.W. von, [1832] 1994, Faust, Part II, transl. D. Luke, Oxford University Press, Oxford.
Kempf, H., 2007, Comment les riches détruisent la planète, Éditions du Seuil, Paris.

Keynes, J.M., 1920, The economic consequences of the peace, Macmillan and Co., London.

Keynes, J.M., [1930] 1952, 'Economic possibilities for our grandchildren', in J.M. Keynes (ed.), Essays in persuasion, pp. 364-365, 372-373, Rupert Hart-Davis, London.

Keynes, J.M., [1936] 1973, The general theory of employment, interest and money. Macmillan/The Royal Economic Society, London. PMCid:PMC1350315

Latouche, S., 2004, Survivre au développement, Mille et Une Nuits, Paris. PMCid:PMC3323070

Monbiot, G., 2006, Heat: How to stop the planet burning, Allen Lane, London.

Pelly, R., 2011, 'Infinite God, finite resources', paper presented at a seminar by the Wellington Institute of Theology, Wellington, 06 August 2011.

Petrella, R., 2004, Désir d'humanité; le droit de rêver, Éditions Labor, Brussels.

Schuurman, E., 1995, Perspectives on technology and culture, transl. J.H. Kok, Dordt College Press, Sioux Center.

Schuurman, E., 2003, Faith and hope in technology, transl. John Vriend, Clements, Toronto.

Simons, P., 2011, 'Rhizoids, technicism and economism', Koers - Bulletin for Christian Scholarship 76(3), 539-557. http://dx.doi.org/10.4102/koers.v76i3.41

Skidelsky, R. \& Skidelsky, E., 2012, How much is enough? The love of money and the case for the good life, Allen Lane (Penguin), London.

Solow, R.M. 1987, 'Policies for economic growth', in A. Knoester \& A.H.E.M. Wellink (eds.), Tinbergen lectures on economic policy, p. 140, Elsevier, Amsterdam.

Uchatius, W., 2009, 'Wir könnten auch anders', Die Zeit, 20 May, pp. 15-20.

Veblen, Th., [1899] 2001, The theory of the leisure class, The Modern Library, New York. 